\title{
Author Correction: Economic value of protected areas via visitor mental health
}

\author{
Ralf Buckley (1D, Paula Brough (1D), Leah Hague, Alienor Chauvenet (D), Chris Fleming (1), Elisha Roche (D), \\ Ernesta Sofija (1) \& Neil Harris (1)
}

Correction to: Nature Communications https://doi.org/10.1038/s41467-019-12631-6, published online 12 November 2019.

The original version of this Article contained an error in the spelling of the author Alienor Chauvenet, which was incorrectly given as Ali Chauvenet.

Reference [90] originally incorrectly read 'Rutstein, S. E. et al. The annual burden of seasonal influenza in the US veterans affairs population. Glob. Publ. Health 12, 1269-1281 (2017).' The corrected version of this reference is 'Rutstein, S. E. et al. Hidden costs: the ethics of cost-effectiveness analyses for health interventions in resource-limited settings. Global Public Health 12, 1269-1281 (2017).'

Reference [91] originally incorrectly read 'Benson, T. We propose a novel measure for social welfare and public health: capabilityadjusted life-years, CALYs. J. Med. Econ. 20, 107-113 (2017).' The corrected version of this reference is 'Benson, T. The load model: an alternative to QALY. J. Med. Econ. 20, 107-113 (2017).'

Reference [97] originally incorrectly read 'Hlatky, M. A. The social value of childhood vaccination in the United States. JAMA Cardiol. 2, 534-535 (2017).' The corrected version of this reference is 'Hlatky, M. A. Are novel anticoagulants worth their cost? JAMA Cardiol. 2, 534-535 (2017).'

Reference [104] originally incorrectly read 'Whiteford, H. A. et al. Interpreting scores on the Kessler psychological distress scale (K10). Aust. NZ J. Publ. Health 25, 494-497 (2001).' The corrected version of this reference is 'Whiteford, H. A. et al. Estimating treatment rates for mental disorders in Australia. Austr. Health Rev. 38, 80-85 (2014).'

Reference [115] originally incorrectly read 'Smyth, R. et al. Tourism and natural world heritage: a complicated relationship. Pop. Environ. 32, 353-375 (2011).' The corrected version of this reference is 'Smyth, R. et al. A study of the impact of environmental surroundings on personal well-being in urban China using a multi-item well-being indicator. Popul. Environ. 32, 353-375 (2011).' This has now been corrected in both the PDF and HTML versions of the Article.

Published online: 10 December 2019

Open Access This article is licensed under a Creative Commons Attribution 4.0 International License, which permits use, sharing, adaptation, distribution and reproduction in any medium or format, as long as you give appropriate credit to the original author(s) and the source, provide a link to the Creative Commons license, and indicate if changes were made. The images or other third party material in this article are included in the article's Creative Commons license, unless indicated otherwise in a credit line to the material. If material is not included in the article's Creative Commons license and your intended use is not permitted by statutory regulation or exceeds the permitted use, you will need to obtain permission directly from the copyright holder. To view a copy of this license, visit http://creativecommons.org/licenses/by/4.0/.

(C) The Author(s) 2019 